\title{
Ruslands selvskabte islamiske radikalisering
}

\section{Maria Lipman}

\section{Nordkaukasus er for Rusland, hvad Afghanistan med dets Taleban eller stammeområderne i Paki- stan ville være for USA, hvis de var amerikanske stater}

Journalister, der har skrevet om selvmordsbombningerne i Moskvas metro 29. mart 2010, har som regel omtalt dem som tilbagevenden for terrorismen i den russiske hovedstad efter flere års relativ ro. Moskva var i realiteten senest mål for terrorangreb i 2004. Men mens den beskrivelse teknisk set er korrekt, er det vildledende at adskille grusomhederne i Moskvas metro, hvor 40 blev dræbt, og mange flere sårede, fra de terroristiske aktiviteter andre steder på russisk jord, nemlig i Nordkaukasus.

De seneste eksplosioner i Moskva var nye alarmerende udslag af den kroniske plage, som situationen i Nordkaukasus er blevet. Rusland har levet med den grimme virkelighed i næsten to årtier, men føderationspolitiets sporadiske straffeaktioner kombineret med fortsat generel negligering har yderligere forværret situationen. Den seneste retorik og visse politiske skridt vedrørende Nordkaukasus kan tyde på, at Kreml leder efter en ny angrebsvinkel. Men uanset hvad der gøres, er udfordringerne fra regionen så mange og så rodfæstede, at Rusland formentlig vil plages med dem i mange år fremover.

Det nordkaukasiske territorium, der strækker sig fra Sortehavet til Det Kaspiske Hav i det europæiske Rusland, har adskillige administrative enheder og republikker, der alle har svage og dysfunktionelle økonomier, som er helt afhængige af tilskud fra Moskva.

Territoriet er hjemsted for fattigdom, ekstrem høj arbejdsløshed, grasserende kriminalitet og korruption, der virker ekstrem selv efter russiske standarder. 


\section{Klanfejder som dagligdag}

I tillæg hertil er Nordkaukasus befolket af massevis af etniske grupper og ofte belastede eller fjendtlige interetniske relationer. Klanfejder er dagligdagen i det lokale liv, og flere grænsekonflikter skærper spændingerne. Nordkaukasus' folk klamrer sig i stigende grad til traditionelle sædvaner og kulturer.

Det forhold at folk i Nordkaukasus overvejende er muslimer, betyder at den øgede kulturelle splittelse med resten af Rusland fører til stærkere islamisering af regionen. Den seneste historie med blodige krige i Tjetjenien koblet sammen med de barske samfundsøkonomiske forhold er frugtbar jord for radikale former af islam. Den islamiske terrorisme er utvivlsomt værre i Rusland end i Europa og USA. Nordkaukasus er del af Rusland. Beboerne i området er russiske borgere, og lokalområderne er finansieret af det russiske føderationsbudget. Det er som hvis Afghanistan med dets Taleban eller stammeområderne i Pakistan var en amerikansk stat.

Tjetjenien er bedre kendt i verden end andre dele af Nordkaukasus på grund af de to på hinanden følgende krige fra 1994. I Sovjetunionen var Tjetjenien ikke en af de 15 republikker, men en underdivision af en af dem, Sovjetrepublikken Rusland, som blev til dagens Russiske Føderation. Da Sovjetunionen kollapsede og efterlod sig 15 uaf- hængige lande, forblev Tjetjenien, hvor modstræbende det end var, inden for den nye russiske stat.

Tjetjenerne deler erindringer om to århundreders brutale kolonikrige under tsarmagten såvel som sovjetmagten. Stålfast tjetjensk modstand imod den russiske undertrykker er en integreret del af dens kolonihistorie.

Boris Jeltsins regering svarede på oprør med krig i fuld skala. Efter USSR's sammenbrud blev de væbnede styrker radikalt svækket med for lidt træning og for få penge. Rædsomme forbrydelser blev begået af begge parter. Under det blodigste slag i starten af 1995 blev den tjetjenske hovedstad Grosnij - i sovjettiden en industriby med omkring 400.000 indbyggere - stort set totalt raseret. Omkring 5.000 føderationsstyrker blev dræbt i den krig. Antallet af dræbte tjetjenske soldater varierer fra tre til fire tusinde. Antallet af civile ofre forbliver ukendt, men skønnene er fra 25.000 til 40.000. (Ifølge tjetjenske skøn over 100.000 . Red.)

Den russiske offentlighed støttede ikke krigen. På den ene side lykkedes det ikke Kreml at forklare, hvorfor unge russiske værnepligtige, der var helt uforberedte til kamp i det barske Kaukasus, skulle sendes ud imod en formidabel fjende, der var på hjemmebane i bjergområderne og bakket op af lokalbefolkningen. På den anden side spillede den nye private tv-kanal NTV nogenlunde 
samme rolle som unge amerikanske journalister under USA's krig i Vietnam. De bragte de grusomme billeder fra krigene ind i folks hjem, og det skabte stærke antikrigsfølelser.

Da Jeltsin i 1996 søgte genvalg, var han tvunget til våbenhvile og efterfølgende at standse krigen - ellers forekom det umuligt, at han kunne genvælges. Fredsaftalen i 1996 var beviset for Ruslands ydmygende svaghed: en tidligere supermagt var ude af stand til at undertvinge sin egen lillebitte region.

Det er dog værd at bemærke, at i modsætning til mange dommedagsforudsigelser, valgte ingen af de andre nordkaukasiske republikker at følge Tjetjeniens løsrivelse eller at tilslutte sig de tjetjenske krigere. Naboerne foretrak at holde sig væk fra Tjetjeniens kamp med Moskva.

Den efterfølgende 'fred' og Tjetjeniens de facto uafhængighed bragte klare beviser for, at det ikke var en levedygtig stat. De facto regeringen viste sig ude af stand eller uvillig til at styre deres land eller på nogen måde sørge for deres befolkning. Kidnapninger for løsepenge blev en almindelig levevej, vilkårlige brutale overgreb fandt sted overalt. De selv samme mennesker, som sympatiserede med den tjetjenske sag og søgte at hjælpe så som journalister og hjælpearbejdere, blev ofte taget som gidsler, eller det der er værre.

I en særlig grusom hændelse blev fire udenlandske ingeniører, tre briter og en newzealænder, halshugget i Tjetjenien i 1998. I 1999 invaderede en tjetjensk styrke naborepublikken Dagestan, og på samme tid dræbte eksplosioner i beboelsesejendomme i tre russiske byer omkring 300 mennesker.

\section{Ny krig uundgåelig}

Herefter var en ny krig uundgåelig, og den anden tjetjenske krig begyndte kort efter, at den skrøbelige og upopulære præsident Boris Jeltsin trådte tilbage og overlod Rusland i Vladimir Putins hænder. Putins tjetjenske krig varede tre år, og kostede flere end 4.500 russiske soldater livet. Ifølge officielle militære rapporter blev flere end 15.000 tjetjenske krigere dræbt, og menneskerettighedsaktivister har skønnet, at antallet af civile ofre var mellem 10.000 og 20.000. Putins krig førte oprørende grusomheder og umenneskelighed med sig, men denne gang kunne Kreml påberåbe sig sejr. Da den storstilede militære kampagne var ovre, arrangerede Kreml i marts 2003 en omstridt folkeafstemning, der vedtog en ny tjetjensk forfatning. Ifølge den nye forfatning er Tjetjenien en del af Den Russiske Føderation, og i oktober 2003 blev den af Moskva udpegede leder af republikken, Akhmed Kadyrov, 'valgt' til præsident.

Tjetjenien kunne næppe kaldes fredelig. Krigen var officielt afsluttet, men 'anti-terroristoperationerne' fortsatte. Den Moskva-tro rege- 
ring blev støttet af russisk militær og af russiske sikkerheds- og politistyrker. De slog angrebene fra tjetjenske krigere, der gemte sig i bjergene, tilbage og gennemførte straffeekspeditioner mod dem, som de mistænkte for at hjælpe den antirussiske modstandsbevægelse.

Resultatet blev en ondartet voldsspiral, hvor føderationsstyrkerne rutinemæssigt pågreb, torturerede $\mathrm{og}$ dræbte lokale, der var under mistanke for at støtte eller sympatisere med de tjetjenske krigere, og hvor sidstnævnte førte en brutal krig mod russiske soldater og gennemførte terrorangreb mod civile i Moskva og andre russiske byer.

De mest horrible terrorhandlinger indbefatter angrebet mod Dubrovka-teatret i Moskva i slutningen af 2002, hvor tjetjenske terrorister tog 912 tilfældige publikummer og teaterfolk som gidsler i tre døgn, og det uhyrlige terrorangreb i september 2004 på en skole i Beslan i Nordossetien, hvor mere end 1.200 skolebørn og voksne blev holdt som gidsler i over to døgn. I Moskva blev 129 gidsler dræbt, og i Beslan mistede omkring 330 personer livet, over halvdelen af dem børn.

I maj 2004 var præsident Kadyrov blevet dræbt i et bombeangreb.

\section{Fremkomsten af radikal islam}

Midt i det første årti i 2000-tallet var løsrivelse ikke længere et spørgsmål i Tjetjenien. Moskva erstattede den myrdede leder med hans søn, Ramson Kadyrov, og valgte gradvist en såkaldt tjetjeniseringspolitik. Russerne forsynede den ny tjetjenske præsident med kapital, og til trods for at der stadig var føderationsstyrker i landet, fik han stort set frie hænder til at skride ind over for de antirussiske krigere.

Før han selv blev præsident, støttede Ramsan Kadyrov sin far, og han stod bl.a. i spidsen for en slags bevæbnet milits, som var berygtet for sin grusomhed. Kadyrov blev almindeligvis beskrevet som en mand, der var villig til at bruge rå magt. I sin nye rolle som Tjetjeniens præsident benyttede han sig af skånselsløse repressalier som tortur, kidnapning af krigernes familier, nedbrænding af deres huse osv.

Moskva vendte det blinde øje til hans metoder og ignorerede rapporter fra menneskerettighedsaktivister, der selv blev almindeligt fordømt og bagvasket af Kremls loyale, statskontrollerede medier. I de forløbne år er Kadyrovs politiske modstandere såvel som fremtrædende menneskerettighedsaktivister og journalister, som har dokumenteret overgrebene i Tjetjenien, systematisk blevet elimineret en efter en.

Mordet på Anna Politkovskaya er det bedst kendte eksempel, men der er mange andre. De er blevet myrdet i såvel Tjetjenien som udenfor: i Moskva, Wien, Istanbul og Dubai. Men uanset hvem gerningsmændene eller bagmændene til disse mord 
har været, er de sluppet af sted uden straf.

"Det er svært at ignorere det faktum, at i løbet af de sidste to år er praktisk talt alle, der har udfordret Kadyrovs greb om magten, afgået ved døden”, sagde Stanislav Belkovsky, politisk analytiker med base i Moskva, i et interview. Oleg Orlov, der er formand for menneskerettighedsorganisationen Memorial, hævdede at Kadyrov i virkeligheden var ansvarlig for mordet i 2009 på Natalia Estemirova, menneskerettighedsaktivist og journalist, der boede og arbejdede i Tjetjenien (se artikel af Oleg Orlov side 17). Kadyrov svarede igen med at rejse en straffesag mod Orlov. for 'bagvaskelse' og krænkelse af sin 'ære og værdighed'.

Gradvist leverede Kadyrov faktisk, hvad Moskva forventede af ham: han bibragte Tjetjenien en grad af stabilitet. Han har muligvis bidraget til genopbygningen af Tjetjenien efter to ødelæggende krige, så selv om omfanget af snyd og bedrag er enormt, foretrækker Moskva også her at se den anden vej. Til gengæld for højt skattede tjenester over for Kreml er Kadyrov helt fritaget for at stå til ansvar.

Kremls afhængighed af ham satte Kadyrov i stand til støt at udvide sin indflydelse. På hans opfordring erklærede Kreml i 2009, at de anti-terroroperationer, som var blevet igangsat i Tjetjenien ti år tidligere, nu var et afsluttet kapitel, og overlod det således i endnu højere grad til Kodyrovs forgodtbefindende at anvende magt i sin region. Det kan med nogen ret hævdes, at Kadyrov i dag har større uafhængighed, end hans oprørske forgængere - alle dræbt i de to krige med Rusland nogensinde havde gjort sig forhåbninger om.

\section{Svag islam i 1990'erne}

I de tidlige 1990'ere, da den første tjetjenske krig brød ud, var årsagen mere politisk end religiøs. Begge de tjetjenske separatistledere, Dsjokhar Dudajev (dræbt i 1996) og Aslan Maskhadov (dræbt i 2005), havde været loyale sovjetiske officerer. Dudajev, der var general i flyvevåbnet, kæmpede i 1986-87 i Afghanistan. Hans etniske eller eventuelle religiøse tilhørsforhold hindrede ham åbenbart ikke i at planlægge og udføre militære operationer mod afghanske muslimer. Maskhadov var oberst og tjente i de sovjetiske og kortvarigt i de russiske væbnede styrker indtil 1992.

Skønt Nordkaukasus traditionelt har været muslimsk, stod islam svagt i 1990'erne. De voksne i Tjetjenien havde fået en sekulær sovjetisk opdragelse, og i 1990'erne havde russisk kultur stadig en stor tiltrækningskraft. Men den ny generation og blandt dem den nuværende tjetjenske præsident Ramsan Kadyrov voksede op under andre vilkår.

Russiske væbnede styrker hærgede landet, og den eksisterende soci- 
al- og undervisningsstruktur, der byggede på russisk sprog og kultur, var ødelagt. Islam har i det forløbne årti fået et fast tag i Tjetjenien og andre steder i Nordkaukasus. De yngre er i stigende grad blevet påvirket af islamisk religion og kultur, ikke sjældent i dens mere radikale udgaver. Illegale ekstremistiske grupper opfordrede til hellig krig overalt i Rusland.

Der findes angiveligt træningscentre for selvmordsbombere i Nordkaukasus. Den kamp mod islamiske ekstremister, som de russiske specialstyrker og de Moskva-tro regionale regeringer i Nordkaukasus udkæmpede, har ikke fået bugt med terrorismen. I foråret 2009, netop som de russiske myndigheder erklærede anti-terroroperationerne for overstået, meddelte ekstremistiske hjemmesider, at nye terroraktioner ville ramme civile, at nye selvmordsbombere blev trænet, og at 'krigszonen' ville blive udvidet ud over Kaukasus' område til at omfatte russisk territorium i det hele taget.

\section{'Tjetjenisering'}

I de senere år har Rusland udvidet 'tjetjeniseringspolitikken' til også at omfatte andre regioner i Nordkaukasus. Moskva anbragte loyale ledere, udstyrede dem med kapital og begrænsede styringen til lejlighedsvis brug af magt til at bekæmpe terror. Ingusjetien er et eksempel på hvad en sådan politik kan medføre.
I 1990'erne var Ingusjetien velsignet med en klog leder, Ruslan Aushev, der var i stand til at opretholde 'neutralitet' og på den måde forhindre, at hans republik blev trukket ind i den tjetjenske krig, selv om Ingusjetiens ganske lille territorium strækker sig langs Tjetjeniens vestlige grænse. Præsident Aushev blev beundret, endog tilbedt, af sit folk. Han popularitet gjorde ham uafhængig, han træf sine egne beslutninger, også hvad angik forbindelserne til de tjetjenske separatister, og det fik Kreml til at være på vagt.

I Putins første embedsperiode blev Aushev tvunget fra magten og erstattet af en mand valgt af Kreml, en loyal, men helt igennem inkompetent præsident. Hans regering forfulgte skånselsløst enhver, der var under mistanke for religiøs ekstremisme eller på anden måde blev betragtet som en trussel mod den ny ingusjetiske leders autoritet. Ofrene for den brutale behandling hævnede sig på politiet, og endnu værre straffeforanstaltninger fulgte. Mange i Ingusjetien blev frast ødt af hans hårdhændede og grumme metoder. Ingusjetien, der havde været fredeligt under præsident Aushev, blev nu næsten dagligt skueplads for statsfjendtlig virksomhed og terror såvel som grove krænkelser af menneskerettighederne.

Da Kreml endelig besluttede at fjerne ham, var der sluppet for mange voldelige kræfter løs, og situatio- 
nen kom ud af kontrol. Desperate hævnere, indbyrdes rivaliserende klaner, religiøse radikale og kriminelle kræfter næret af korruption alle var involveret i voldsomme kampe med deres modstandere.

Den nyligt udpegede ingusjetiske leder Junus-Bek Jevkurov forsøgte sig med en mere rimelig strategi, men i juni 2009, omkring otte måneder inde i hans embedsperiode, var han nær blevet dræbt i et attentat. Jevkurov vendte tilbage til Ingusjetien endnu inden han var fuldt restitueret. I dag kæmper han for at skabe ro i Ingusjetien, og hans politik - barsk forfølgelse af kriminelle og terrorister kombineret med en human behandling af befolkningen - støttes af menneskerettighedsforkæmpere. Men Kreml havde for længe set gennem fingrene med hans forgænger, og i dag er Jevkurovs fremskridt langsomme og forsigtige.

Republikken Dagestan, der ligger øst for Tjetjenien, er et bjergrigt område med snesevis af forskellige etniske grupper. I de senere år har islam fået stærkere fodfæste i denne region, og religiøs ekstremisme er på fremmarch. Sikkerhedssituationen er alvorligt forværret: der rapporteres jævnligt om drab på lokale embedsmænd og politifolk.

En journalist fra Newsweek skrev i sommeren 2009: "I Dagestan sprænges politifolk i luften, skydes i vejkanten og myrdes i deres senge" som led i en etnisk kamp mellem de politisk dominerende etniske grupper og dusinvis af mindre privilegerede.

Det står lidt bedre til i andre etniske republikker, men tilhængere af radikal islam er ikke usædvanlige. I oktober 2005 var Naljtjik, hovestaden i Kabardinien-Balkarien, skueplads for et blodigt slag mellem lokale repræsentanter for ordensmagten og ikke-identificerede krigere. Omkring 100 krigere og 14 civile blev dræbt. Ordensmagten mistede 35 mænd.

I Tjetjenien, der i en kort periode syntes mere stabil end Dagestan og Ingusjetien, oplevede man i 2009 en række dødbringende angreb på politifolk og embedsmænd. Kadyrovs regeringstid har hvad angår overgreb på menneskerettighedsforkæmpere været kendetegnet af en afskyelig rekord; men sommeren 2009 var særlig slem: Der blev begået to mord på menneskerettighedsforkæmpere på mindre end en måned (ovenfor omtalte Natalia Estemirova var et af ofrene). Det stod klart at tjetjeniseringspolitikken var slået fejl, og at det kun var et spørgsmål om tid, før volden spredte sig ud over Kaukasus' grænser. Nogle måneder senere fulgte selvmordangrebene i Moskvas metro.

\section{Ingen strategi imod radikalisering}

Den pludselige stigning i volden i Nordkaukasus var en logisk konsekvens af den lokale politik og af 
Kremls ligegyldighed. Efterhånden som regionens forfærdelige sociale problemer hobede sig op, og den gradvist blev yngleplads for radikal islam, indskrænkede den russiske regering som oftest sin indsats til lejlighedsvise anti-terroraktioner og fæstede i øvrigt sin lid til hårdhændede lokale ledere, der var holdt oppe af rigelige føderale midler. Socialpolitik, kultur, uddannelse, lov og orden var næppe anliggender Kreml tog sig af.

Politisk set kan ledelsen sagtens slippe af sted med det. Rusland har ikke en politisk opposition, der kan udfordre Kremls politik, og folk i almindelighed holder ikke Kreml ansvarlig for at Nordkaukasus bliver stadigt mere ustabilt. Så længe volden holdes væk fra deres hjem, tager folk næppe notits af udviklingen i denne urolige region.

Den tid hvor NTV var med til at skabe antikrigsfølelser i den russiske befolkning er for længst ovre. De nationale tv-kanaler er underlagt stram statskontrol, og dækningen af Nordkaukasus er omhyggeligt filtreret eller rettere sagt stærkt begrænset. I virkeligheden er den russiske offentlighed ikke interesseret i nyheder fra det område. Det antages at situationen dér er håbløs, og eftersom man ikke kan gøre noget for at forbedre den, er det bedre ikke at tænke på den overhovedet. Nordkaukasus opfattes heller ikke helt som en del af Rusland.

Også før eksplosionerne i Moskvas undergrundsbane var det åbenbart for enhver, der ønskede at vide det, hvordan det hele hang sammen i Nordkaukasus. Caucasian Knot, en enestående russisk hjemmeside som dagligt dokumenterer udviklingen $\mathrm{i}$ Nordkaukasus, mindede dagen efter eksplosionerne i Moskva om, at mellem maj 2009 og januar 2010 havde der i Tjetjenien, Ingusjetien og Dagestan været 15 selvmordsangreb som kostede 69 mennesker livet og sårede 354. Caucasian Knot har indgående rapporteret om disse angreb såvel som den daglige vold i regionen, men for det brede russiske publikum har det simpelthen ikke nyhedsværdi.

Den rapport fra Caucasian Knot, der blev offentliggjort i slutningen af maj, opsummerer udviklingen siden eksplosionerne i Moskvas metro: yderligere fem selvmordsbombninger i Dagestan og Ingusjetien i løbet af mindre end to måneder. Efter forlydender blev en selvmordsbomber dræbt af det lokale politi i Tjetjenien, inden han nåede at udløse sin sprængladning.

Den 26. maj dræbte en eksplosion mindst syv og sårede over 40 foran et teater i Stavropol, en by i det sydlige Rusland ikke langt fra flere etniske republikker i Nordkaukasus. I skrivende stund er motivet til denne forbrydelse endnu ukendt, men politiet nævner 'yderliggående nationalisme' som en af flere muligheder.

Selvfølgelig har Kreml indset, hvor alvorlig situationen er. Den of- 
ficielle politistatistik, som præsident Dnitrij Medvedev citerede i maj 2010, omtaler 544 terrorrelaterede forbrydelser i Nordkaukasus i 2009, og 235 repræsentanter for ordensmagten er blevet dræbt; flere end 10 velkendte journalister og menneskerettighedsaktivister blev i løbet af 2008-2010 myrdet

Få måneder før angrebene i Moskvas metro udpegede præsident Medvedev en ny befuldmægtiget udsending til Nordkaukasus. I modsætning til andre føderale udsendinge $\mathrm{i}$ denne region er Aleksandr Khloponins professionelle baggrund hverken de væbnede styrker, specialpolitiet eller sikkerhedstjenesten. Han har været en succesrig forretningsmand og dernæst guvernør i Krasnojarsk regionen, en stor og højt udviklet provins i Sibirien. Dette valg antyder at Kreml overvejer en ny og blødere strategi, der lægger vægt på at sætte økonomiske projekter i gang og skabe forretningsmuligheder i Nordkaukasus.

Den ny strategi skyldes måske, at urolighederne i Nordkaukasus udgør en alvorlig trussel mod vinterolympiaden i 2014 . Legene skal efter planen finde sted i Sotji, en by der kun ligger få hundrede kilometer væk. Putin har personligt investeret en hel del energi i at overtale Den Internationale Olympiske Komite til at vælge Sotji frem for dens konkurrenter og ønsker tilsyneladende ikke, at hans yndlingsprojekt skal undermineres af yderligere op- løsning i Nordkaukasus. Men uanset om Khloponins udpegning er foranlediget af det kortsigtede mål at sikre vinterlegene i Sotji eller ej, så kræver omfanget af den nordkaukasiske udfordring en hel del mere: en langsigtet, flerstrenget national forpligtelse.

\section{Ikke medborgere}

Efter angrebene i Moskvas metro gav præsident Dmitrij Medvedev udtryk for noget der lød som netop den form for strategisk tænkning. Han talte om at skabe "det rigtige miljø for uddannelse, for at gøre forretninger, for at få bugt med kammerateri ... og naturligvis for at gøre op med korruption" i Nordkaukasus.

I midten af maj diskuterede Medvedev situationen i Nordkaukasus med en gruppe menneskerettighedsaktivister. Selv om en del af dem helt tydeligt holdt sig tilbage ud fra et ønske om at tækkes præsidenten og deres lokale ledere, var nogle få erfarne aktivister ubøjelige og temmelig åbenhjertige. De fortalte Medvedev om civile, der var blevet tortureret til døde af det lokale politi; om 'ingen-overlevende' taktikken, der blev anvendt under særlige politiaktioner; om folk der forsvandt (for bare at nævne et tilfælde ud af mange hundrede: Zarema Gaisanova, en etnisk tjetjener der arbejdede for Dansk Flygtningehjælp, forsvandt under en særlig politiakti- 
on i Tjetjenien i oktober 2009) og om henrettelser uden dom.

De fortalte om 'sikkerhedsaftaler', hvor politiet betalte krigerne, så at de ikke angreb dem, samtidig med at lokale regeringsembedsmænd udstedte trusler - offentligt, endda på tv - mod terrormistænktes familier; om hvordan frygten for brutale repressalier afholdt folk fra at klage til myndighederne, ja selv til menneskerettighedsaktivisterne.

Aktivisterne talte om dårlig skolegang, om 'ukontrolleret, kaotisk islamisering', om allestedsnærværende pengeafpresning og korruption og om en dyb mistillid mellem befolkningerne i Nordkaukasus og de lokale myndigheder.

Dette nedslående vidnesbyrd er offentliggjort på Kremls hjemmeside, hvor alle kan læse det, men det vil sandsynligvis ikke vække røre i offentligheden. Nationen som helhed såvel som regeringen behandler ikke den nordkaukasiske befolkning som deres landsmænd - i stedet betragter de dem sædvanligvis som en mistænkelig kultur eller simpelthen som en trussel. Det er en af grundene til, at Medvedevs retorik næppe kan forventes at blive omsat til en sammenhængende og effektiv strategi rettet mod at normalisere Nordkaukasus.

Men der er andre forhindringer: korruption, embedsmisbrug og foragt for loven plager ikke kun Nordkaukasus, de er substansen i den russiske styreform, der bygger på politik monopol og uansvarlighed.

Maria Lipman er redaktør af Pro et Contra, tidsskrift udgivet af Carnegie Center Moskva samt flittig kommentator i uafhangige russiske medier.

(Oversat fra engelsk af Brita $V$. Andersen) 